\title{
EVALUATION OF LOCATION FACTORS OF BUSINESSES BY LOCAL AUTHORITIES OF EASTERN POLAND, WITH A PARTICULAR EMPHASIS ON SPATIAL POLICY
}

\author{
Izabela Serocka, M.Sc. \\ Faculty of Economics \\ University of Warmia and Mazury in Olsztyn \\ e-mail: izabela.serocka@uwm.edu.pl
}

\begin{abstract}
Conditions underlying the undertaking and developing of a business enterprise in a specific location are strictly connected to the state and any possible modifications of the spatial management in a given area, and the local government of every municipality is obliged to ensure spatial order and to manage the land resources so as to take into account their economic assets.

The main purpose of this study was to identify the role of a variety of relevant factors as well as the activities performed by local governments in eastern Poland that arise from with the local policy of a municipality, the smallest unit in Poland's administrative division, in connection with the location of business enterprises.

The research enabled us to determine what activities in the domain of spatial policy are implemented by local governments and what role they play in the enhancement of economic values of a municipality. The results also helped to indicate which spatial policy factors lose and which gain importance in the context of conducting a business activity. The most important factor in terms of the location a business investment in a given area is the active implementation of the municipality's spatial policy. The factor that gains the highest importance in the eyes of entrepreneurs is the condition of technical infrastructure.
\end{abstract}

Key words: location theory, entrepreneurship, spatial policy, location factors.

JEL Classification: R30, H00, R12, L26, O10.

Citation: Serocka I., 2019, Evaluation of Location Factors of Businesses by Local Authorities of Eastern Poland, with a Particular Emphasis on Spatial Policy, Real Estate Management and Valuation, vol. 27, no. 1, pp. 49-58.

DOI: 10.2478/remav-2019-0005

\section{Introduction}

A decision to start and develop a business enterprise is influenced by a variety of location factors. Location conditions determine, to a different extent, the growth of entrepreneurship in a particular area. On the other hand, these factors can be shaped directly by local authorities, which, through various initiatives, create conditions for conducting business.

In view of the importance of location factors connected to the spatial policy of municipalities and activities in the field of spatial management, it is worth taking a closer look at opinions concerning these issues. According to the local authorities in the provinces of eastern Poland, do particular location factors gain or lose significance? Is the spatial policy of municipalities an important factor? What actions in the field of spatial policy have been undertaken by local governments in the provinces of eastern Poland? 


\section{Literature review - location decisions of enterprises versus the spatial policy of municipalities}

The growth of a business enterprise depends largely on its location ${ }^{1}$, which should not be chosen at random but selected so as to ensure that a given business entity achieves specific production outputs at the smallest possible social costs of production. Thus, location should not collide with interests of other branches of economy, nor should it be contradictory to the proper management of space in a given location (FIERLA 1973).

The problem of locating a facility is common to all businesses. Location decisions are very important because they are often classified as strategic decisions. They usually result in significant fixed costs and, more importantly, they have considerable impacts on the growth prospects of a firm. As a result, location decisions are made very carefully as the executives are aware of their significant economic importance (PARTOVI 2006; BERMAN et al. 2017). Because of this, decisions where to localize an investment and the risk involved need to be considered from the point of view of the investor, but also as it is perceived by the local government, owners of real estate properties, the local community, various institutions and other entities active in a given area (KUCIŃSKI 2014; NIEDZIÓŁKA 2016), because a chance that an enterprise is successful is greater in a more predictable business environment. The decision made by an enterprise owner to carry out an investment in a given location, as well as the future development of this project, are influenced by location factors, i.e. a complex set of phenomena that occur both within the said enterprise and in its surroundings² (GODLEWSKA-MAJKOWSKA 2016). The extent to which different locations are suitable for certain functions depends on two factors: the properties of a given territory (internal conditions) and the situation in its surroundings (external conditions). Internal conditions include: natural conditions (e.g. surface relief, technical properties of the ground, soil, natural resources, climate), legal status (e.g. ownership, mortgage loans), the existing land management and utilization solutions. External conditions include: natural conditions and nature preservation (e.g. land relief, geological structure, soil, water and aero sanitary conditions, wastewater and sewage management, municipal waste management), social and demographic conditions (e.g. size of the population, age and employment structure, migration balance, level of education and unemployment), the functional structure of the environs and the spatial relations to supplied markets, the provision of infrastructure, legal conditions (local and supra-local), the economic situation and other circumstances. An investor wants to choose a location with such a set of various factors that will ensure the greatest benefits (BUDNER 2004; ZHENG, SHI 2018).

Space, a location factor, is economically a rare commodity, while being an essential element for setting up and developing a business activity. Companies consider not only the physical dimensions of space but also its shape, geographical location, accessibility, the current and potential land management form, infrastructure, price, costs of occupancy, neighbourhood, access or distance to various resources, and all possible threats. Thus, in terms of local economy, changes in the spatial management within a municipality are equated to changes in the conditions of starting and conducting local business activity, and the local government is the body that decides about such changes, which then have a direct influence on the way local space is developed ${ }^{3}$ (SZTANDO 2003).

Local authorities are increasingly aware of the benefits that every investment can generate. Unfortunately, only some make efforts to attract desirable investment projects. Whether municipalities prefer to conduct a passive search for investors or effectively strengthen the competitive edge and acquire new investment projects depends on the attitudes and goals set by persons and institutions which manage these units. Local authorities are a very important institution in attracting various investment projects - institutions which can significantly contribute to the local and regional

\footnotetext{
1 The classical theory of localization was started by J.H. Thünen (in 1826). This theory was created to explain and predict the spatial formation of various categories of agricultural production. The localization theory was later developed and expanded by A. WeBER (1909), E. M. HoOver (1948), W. ISARD (1956), A. LÖsCH (1961) and others.

2 Perception of localization factors can be different, depending on the level of development of a given country/region. In a less developed economy, such factors as the condition of technical infrastructure are more important; in intermediate economies, the quality of human resources plays a more important role, and innovations, for example, are the most important in the most highly developed economies (RAMíREZ-ALESÓN, FLETA-Asín 2016).

3 Provision of spatial order and land resource management belong to a municipality's own tasks, where the local authorities are obliged to take into consideration economic assets while planning spatial management.
} 
development of the country (MiszCZUK et al. 2007; DZIEMIANOWICZ 2008; RINALDi 2016; Cull et al. 2017).

Efficient and effective local governments, initiating and supporting activities for the areas they represent, are a key to local development. Individual municipalities differ in their development potential, which is composed of such factors as human and social capital, quality of life, institutional and technological capital, as well as the ability to provide funds for economic and social projects (PARYSEK 1997; OKOŃ-HORODYŃSKA 2011; WOLNY et al. 2014).

The management of a municipality's space in terms of local and regional development can be considered one of the key processes. Instruments of the spatial policy in a municipality may have a positive or negative effect on the functions implemented in the municipality, including its economic, social and environmental functions, or tourism ${ }^{4}$. Spatial planning is the principal component of strategic management in a municipality, which takes into account various spheres in which local entities function (local authorities, residents, entrepreneurs) and how they affect the surroundings. The spatial management system in a municipality consists of many interrelated elements. The following documents are said to be most important for the achievement of the objectives defined in the spatial policy of a given municipality: a local spatial management plan, a study of the conditions and directions of the spatial management in the municipality, a multi-year financial plan, and decisions on conditions of land development and development conditions issued by the municipality ${ }^{5}$ (MiCKIEWICZ, NOWAK 2013; SZAJA 2009, 2016).

The spatial policy of all municipalities in Poland is developed on the basis of the Act on Spatial Planning and Development of 27 March 2003 (DzU No. 80, item 717 with subsequent amendments). Development and implementation of a spatial policy in a municipality (including the approval of a study of conditions and directions for spatial development) belong to the domain of the municipality's own tasks.

From the viewpoint of entrepreneurship on a local level, a local spatial management plan (with the Polish acronym of MPZP) is a well-defined instrument for developing plans in the spatial policy of a municipality. It identifies the use of specific land plots and sets of guidelines for their development, in addition to which it delineates limits of areas dedicated to business investments - this is known as the regulatory-supervisory role of an MPZP. For the prospective development of a business, this function has the strongest impact because it either opens or shuts out the possible use of investment territories in a municipality by prospective or existing entrepreneurs. Clarity and transparency of plans greatly helps to make a decision about investing capital by an entrepreneur who intends to invest in a given area (DYLEWSKI 2006; GACZEK 2003; SZTANDO 2003).

Local authorities can also have an indirect influence on the growth of local businesses by decreasing the costs of production. This is particularly important when an investor's decision to select a land parcel for a specific investment project is guided by the lowest possible costs of conducting this business in the future. Authorities of an administrative division unit can lower tax rates on immovable properties or even provide tax exemptions for several years (KŁOSIEWICZ-GÓRECKA 2007; LIZIŃSKA, ŹRÓBEK-RÓŻAŃSKA 2009).

Recapitulating, it can be noticed that there is some feedback between entrepreneurship and the location of enterprises. Hence, the setting up and growth of business entities are strongly correlated with the development of a given region and its character. In consequence, it is important to support entrepreneurs by creating conditions that will be conducive to the development of companies in a given area in a way that will agree with the local resources (WOŹNIAK 2014).

\section{Data and Methods}

The main objective of the research was to determine the importance of various business location factors, including the spatial policy of municipalities and efforts undertaken by local governments in eastern Poland in connection with their spatial policy in the context of starting and running a

\footnotetext{
${ }^{4}$ Spatial policy is defined as conscious and purposeful activity of authorities, consisting in the rational shaping of land management by assigning proper functions to land plots, ones which preserve spatial order and help a given territorial unit to maintain proper and effective functioning of its social and economic system (GACZEK 2003).

5 The decision about development conditions and land management is an instrument which receives critical reviews in literature due to: it being issued individually on each occasion, the risk of corruption, the lack of any guarantee that spatial order and sustainable growth are protected.
} 
business. Provinces situated in eastern Poland (Lubelskie, Podlaskie, Podkarpackie, Świętokrzyskie and Warminssko-Mazurskie) rank relatively low in terms of business investment appeal ${ }^{6}$ and, according to Eurostat, are among the poorest regions of the EU, which is why it seemed very important to explore opinions regarding the location of companies held by local authorities in this part of Europe.

This goal was achieved by analysing the results of a survey conducted among representatives of local authorities in the provinces of eastern Poland. The questionnaire was sent by e-mail in 2017. 215 correctly completed questionnaires were sent back, which corresponded to a $30.3 \%$ rate of return.

Simple statistical methods were employed to interpret the collected data.

\section{Empirical results}

\subsection{Entrepreneurship development and the activity of local authorities}

One of the main drives of the country's socio-economic development is the growth of entrepreneurship, both locally and regionally. On the other hand, the development of entrepreneurship is directly related to investment appeal, which consists of various combinations of location factors. Because local authorities may influence the investment attractiveness of a given region by ensuring adequate conditions for setting up and developing companies, our respondents were asked to determine the level of business development in relation to the investment potential of a given municipality. A level lower than the investment potential was implicated in $56.1 \%$ of municipalities in eastern Poland (Fig. 1). In turn, $40 \%$ of the local governments concluded that the local growth of a business was adequate to the investment possibilities. It was only in $3.9 \%$ of the analyzed municipalities that the growth of entrepreneurship exceeded their investment potential.

the level of development is higher than the investment possibilities offered by the commune

the level of development is adequate to the investment possibilities offered by the commune

the level of development is lower than the investment possibilities offered by the commune

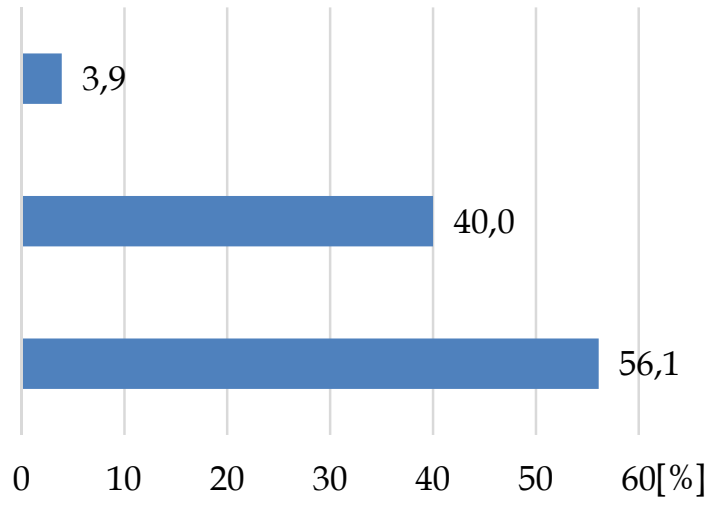

Fig. 1. Level of entrepreneurship development in a municipality versus the municipality's development potential. Source: own study.

The responses may implicate that local authorities in over half of the analyzed municipalities either overrated their investment potential capacity, or else the level of business growth in their territory was relatively low, despite the investment opportunities offered. It is worth remembering that some attractive areas in provinces of eastern Poland have not been developed for business purposes yet due to poor transport accessibility. Another reason is that sometimes the legal status of some of the land managed by a municipality is not correctly reflected in the current Land Register, an undesirable situation that calls for action.

The awareness of local governments regarding their impact on the local development of entrepreneurship very often motivates them to implement specific actions precisely to achieve this aim. Most of the local governments in eastern Poland acknowledged that their real impact on the development of entrepreneurship was moderate (58.1\%). In turn, $16.7 \%$ considered that the impact was high, and a relatively large proportion of respondents (18.1\%) admitted to having a low impact. In contrast, $7.0 \%$ of respondents maintained that local authorities had no influence on investment decisions made by enterprise managers (Fig. 2).

\footnotetext{
${ }^{6}$ In 2016, provinces of eastern Poland were in the last places in the ranking list prepared according to the annual report published by the Institute of Market Research, titled "Investment Attractiveness of Provinces and Subregions of Poland, 2016".
} 


\section{S sciendo}

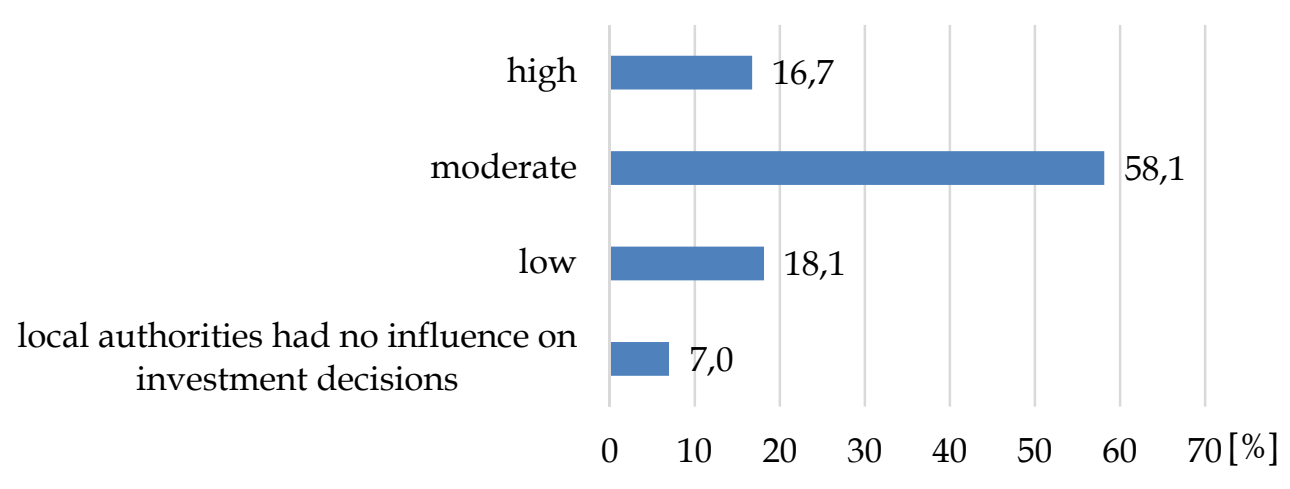

Fig. 2. Evaluation of the actual influence of local authorities on business development. Source: own study.

A question arises why so many respondents $(25.1 \%$ in total) suggested that the influence of local authorities on the development of business was low or absent. This distribution of responses was most likely the result of the experience of local governments in the scope of entrepreneurship stimulation. If a local government had tried to support entrepreneurship and attract investors, but the outcome of such efforts was negligible, then the responses in our survey need not be surprising. The geographical location of eastern Poland and the investment attractiveness of the provinces in this part of our country should also be considered. Unless a given territory is thought to be attractive among investors, actions undertaken by local authorities will most probably fail to generate expected results.

Local governments were also asked to indicate how they had attempted to support entrepreneurship (Fig. 3). Most often, the respondents claimed that their municipality undertook numerous activities in this area, but these were not priority actions $(28.4 \%)$. The same percentage of the respondents indicated that the local authorities implemented very few activities due to limited financial resources and the lack of opportunities to raise more funds. One in four $(25.1 \%)$ of the respondents maintained that supporting entrepreneurship was given priority by the municipality, which made various efforts to this end. Moreover, $18.1 \%$ of the local authorities were aware of the significance of business-support activities and intended to make more efforts in the following years.

supporting entrepreneurship is a priority of the commune, many different activities in this field are taken

a number of actions is taken, but they are not priority ones

only a few actions are taken, but the commune is planning to increase their number in the upcoming years

only a few actions are taken because of limited financial resources and no opportunity to increase them

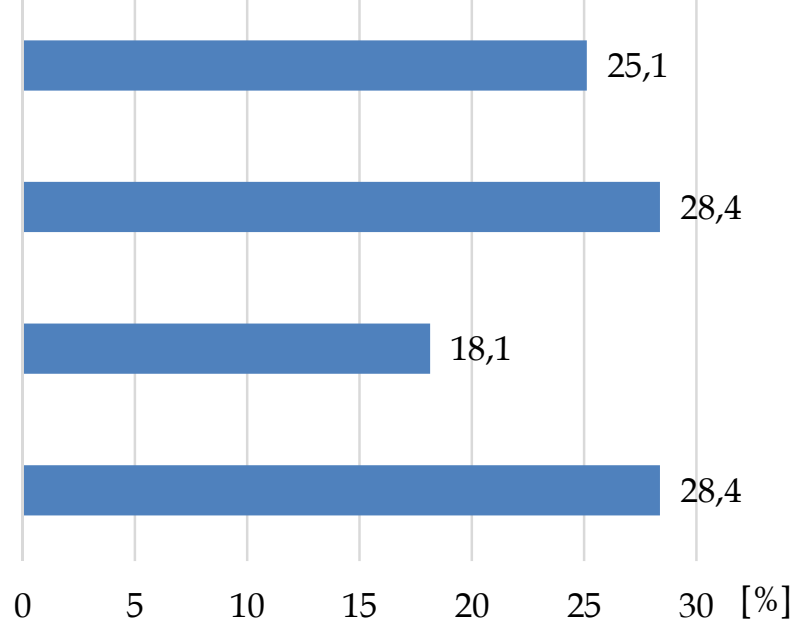

Fig. 3. Activity of local authorities in supporting the development of entrepreneurship in the area of their municipality. Source: own study.

Support given by local governments to entrepreneurs very often generates the intended effects, i.e. broadly understood local development, higher employment, improved quality of life among the residents. The results show that the local authorities are well aware of these correlations, yet they differ in the actions undertaken to assist business development. In a situation where a local government implements only a few actions in order to stimulate a higher level of entrepreneurship due to financial constraints, it is at least worth ensuring that local authorities make efforts to provide high quality and efficient service in local offices and to create a friendly atmosphere for entrepreneurs. 


\subsection{Importance of location factors, including ones connected to the spatial policy of a municipality}

The importance of business location factors is changing. These changes stem from economic development, technological progress, globalization as well as the changing expectations of entrepreneurs. Moreover, the significance of these factors will vary depending on the location of a given municipality/region (for example, in areas where technical infrastructure is well-developed, entrepreneurs tend to pay more attention to factors related to the quality of service in offices). Our respondents, representing local governments in eastern Poland, pointed to the following factors as gaining more importance (from the most frequently indicated factor): the condition of telecommunication technical infrastructure (internet connections) $(74.9 \%)$, water and sewage infrastructure $(68.2 \%)$, attitude towards entrepreneurs in offices $(66.0 \%)$, quality and efficiency of service in offices $(65.6 \%)$, presence of schools, nurseries, crèches (safety and hygienic conditions in these institutions) (63.8\%) (Table 1).

Table 1

Importance of location factors according to the local authorities in the provinces of eastern Poland

\begin{tabular}{ll}
\hline Location factors & $\begin{array}{l}\text { Gains } \\
\text { importance } \begin{array}{l}\text { Dain or lose loses } \\
\text { importance importance }\end{array}\end{array}$ \\
\cline { 2 - 2 } & $\%$ \\
\hline
\end{tabular}

Factors comprising improvements in technical and institutional infrastructure as well as businesssupport activity

\begin{tabular}{|c|c|c|c|}
\hline $\begin{array}{l}\text { Condition of connecting infrastructure (transport and } \\
\text { communication) }\end{array}$ & 59.9 & 31.6 & 8.5 \\
\hline $\begin{array}{l}\text { Condition of telecommunication technical infrastructure } \\
\text { (internet connections) }\end{array}$ & 74.9 & 24.6 & 0.5 \\
\hline Condition of the system of waterworks and sewers & 68.2 & 31.3 & 0.5 \\
\hline $\begin{array}{l}\text { Condition of institutional infrastructure (i.e. activities of } \\
\text { institutions supporting business development) }\end{array}$ & 34.5 & 61.0 & 4.5 \\
\hline Quality and efficiency of service in offices & 65.6 & 34.4 & 0.0 \\
\hline Attitude of office employees to entrepreneurs & 66.0 & 34.0 & 0.0 \\
\hline \multicolumn{4}{|l|}{ Factors which include social services, culture, etc. } \\
\hline Organization of social care & 39.2 & 56.5 & 4.3 \\
\hline $\begin{array}{l}\text { Schools. nursery schools. crèches (safety and hygiene in } \\
\text { educational institutions) }\end{array}$ & 63.8 & 34.8 & 1.4 \\
\hline Quality of health service & 33.5 & 61.7 & 4.8 \\
\hline Free time and relaxation conditions & 58.2 & 37.5 & 4.3 \\
\hline Housing policy of the municipality & 18.5 & 72.7 & 8.8 \\
\hline \multicolumn{4}{|l|}{ Factors including improved public order and safety } \\
\hline Public order and safety & 46.1 & 52.4 & 1.5 \\
\hline Sanitary safety & 35.8 & 60.8 & 3.4 \\
\hline \multicolumn{4}{|c|}{ Factors comprising spatial policy. environmental protection. the financial policy of a municipality } \\
\hline State of the natural environment & 51.5 & 44.7 & 3.9 \\
\hline A municipality's spatial policy (actively implemented) & 59.4 & 39.1 & 1.5 \\
\hline $\begin{array}{l}\text { Availability of municipality-owned land, buildings, office } \\
\text { space, manufacturing and storage floor space }\end{array}$ & 41.7 & 54.9 & 3.4 \\
\hline
\end{tabular}




\begin{tabular}{lllll}
\hline $\begin{array}{l}\text { Costs of leasing or purchasing land from the municipal } \\
\text { resources }\end{array}$ & 41.3 & 54.9 & 3.9 \\
\hline $\begin{array}{l}\text { Costs of renting or purchasing buildings from the municipal } \\
\text { resources }\end{array}$ & 33.7 & 62.4 & 4.0 \\
\hline Local taxes and fees & 45.2 & 51.9 & 2.9 \\
\hline
\end{tabular}

Source: own study.

The spatial policy of a municipality as a location factor gains importance according to $59.4 \%$ of the local governments surveyed. However, $39.1 \%$ of the respondents claimed that its importance did not change, and only $1.5 \%$ suggested that telecommunication as a location factor was becoming less important. Nevertheless, among all the factors submitted for analysis, this one was most often implicated as gaining importance. Therefore, it is confirmed that being in the possession of updated land management plans is very important, and actually most important for investors, who can be certain that setting up a new business in a given location will not give rise to legal problems or require them to wait long for a change in the management plan in a previously selected site.

\subsection{Activities undertaken by local authorities in connection with the municipality's spatial policy versus the location of business enterprises}

It is extremely important for the growth of entrepreneurship that a municipality should have updated and well-organized documentation where the legal status of land resources as well as planned development directions are identified. Local governments in eastern Poland were requested to evaluate the influence of particular actions associated with the spatial policy of municipalities on the growth of business, and concluded that the active implementation of the municipality's spatial policy was the most important factor, as $31.2 \%$ ascribed great importance to it, and $42.3 \%$ - moderate importance (Fig. 4). Active implementation of the spatial policy is manifested mostly by a municipality being in possession of complete and updated documentation of the legal status of the land resources planned to be sold, or constantly striving towards achieving such a state of matters, which has a positive influence on the perception of a given investment site by a potential investor. In turn, the significance of any small steps taken to achieve the above goal was indicated by $17.2 \%$ of the respondents, while $7.9 \%$ did not raise the issue of the active implementation of a municipality's spatial policy. The latter might have been due to the fact that the procedure of developing local land management plans is not only complicated but also time-consuming and expensive, which often discourages local governments from undertaking this step.

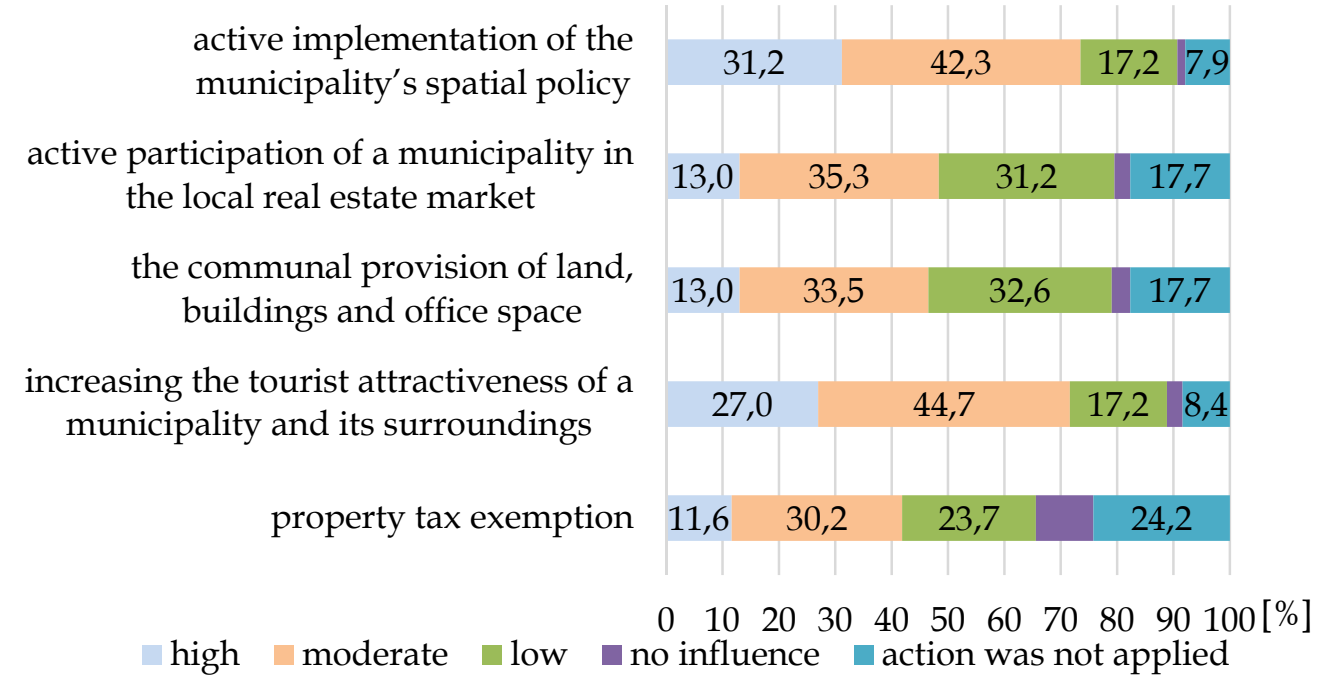

Fig. 4 Importance of activities undertaken by local authorities which influence the location of business enterprises and are connected with spatial policy and environmental protection. Source: own study. 
Another relatively highly valued factor in the area of the spatial policy of a municipality, according to our respondents, was an effort to enhace the tourist attractiveness of a municipality and its surroundings (27.0\% - significant, $44.7 \%$ - moderate importance). In our investigations into the growth of entrepreneurship, we should never lose sight of the fact that the main driving force of this development is man. Establishment and management of a company always involves a certain system of values, be it religion, family, traditions, the socio-cultural environment, or even landscape diversity. Tourist attractiveness of a given site and its surroundings may strongly affect a decision to choose it as an investment area or to remain there once a company has been set up.

The importance of active participation of a municipality in the local real estate market, including market operations, sale, purchase, rental, lease or return of ownership rights to real estate, was ranked lower (13.0\% highly important, $35.3 \%$ moderately important). Very similar assessment values were assigned to activities involving the communal provision of land, buildings and office space. Finally, the least importance was ascribed to property tax exemption $(11.6 \%$ very important, $30.2 \%$ moderately important, $23.7 \%$ - not very important). It is worth noticing that the largest percentage among our respondents admitted to not implementing this solution $(24.4 \%)$, while $10.2 \%$ stated that this was an action that did not affect the location of businesses. Whether or not a municipality offers tax exemptions to entrepreneurs depends on its predicted budget, which will be smaller if tax exemptions are allowed. Nonetheless, it needs to be underlined that tax relief does have a positive effect on decisions to localize business enterprises (cf. PŁAZIAK, SZYMAŃSKA 2014).

\section{Discussion and conclusions}

The growth of business on both local and regional levels is one of the drives of the country's socioeconomic development. This research shows that $56.1 \%$ of the authorities of municipalities in eastern Poland perceive the development of entrepreneurship in their area as being below the investment potential, while $40 \%$ evaluated it as adequate to the possibilities. Only $3.9 \%$ of the respondents admitted that the level of entrepreneurship growth exceeded the investment potential of their municipality. It is noteworthy that some attractive locations in the provinces of eastern Poland have not been developed by companies, for example due to poor accessibility. However, the constantly improving road infrastructure may have a positive influence on the investment attractiveness of such provinces in the future.

The results of our survey concerning activities undertaken by local governments to support entrepreneurship showed that the municipalities were busy in this area, although they did not consider these efforts to be their priority ( $28.4 \%$ of indications). A similar percentage ( $25.1 \%$ of replies) of respondents maintained that the local governments undertook very few activities due to having limited financial resources and being unable to raise more funds. One in four respondents agreed that supporting entrepreneurship was a priority of the local government, which implemented various actions to achieve this goal. On the other hand, $18.1 \%$ of the representatives of local authorities acknowledged the important role of business-support actions and were planning to increase their number in the future years. The research results indicate that local authorities are aware of the positive effects of supporting entrepreneurship and undertake various activities to assist entrepreneurs.

With respect to the importance of all location factors presented in the study, the research showed that the following factors gained importance: the condition of telecommunication infrastructure (internet connections) (74.9\%), water and sewage infrastructure $(68.2 \%)$, attitude of officials to entrepreneurs $(66.0 \%)$, quality and efficiency of service in offices $(65.6 \%)$, presence of schools, nurseries, crèches (safety and hygienic conditions in educational institutions) $(63.8 \%)$.

Furthermore, the results pertaining to the spatial policy of municipalities showed that the location factor, such as the active development and implementation of its spatial policy by a municipality, gains importance according to $59.4 \%$ of the local governments surveyed. The role of this factor did not change in the eyes of $39.1 \%$ of our respondents, and only $1.5 \%$ suggested this location factor was losing importance when making a decision to localize an enterprise. Therefore, it is confirmed that being in possession of updated land management plans is very important, and in fact the most important for investors, who can feel certain that setting up a new business in a given location will not give rise to legal problems or result in having to wait a long time for a change in the management plan in a previously selected site.

Among suggested activities connected to the spatial policy of a municipality, the questioned 
representatives of local governments in eastern Poland assigned the highest importance to the active implementation of the municipality's spatial policy: $31.2 \%$ claimed it was very important and $42.3 \%$ suggested it was moderately important. In contrast, $17.2 \%$ maintained it had little importance and $7.9 \%$ were not at all engaged in the active execution of the municipality's spatial policy. The latter might have been due to the fact that the procedure of developing local land management plans is not only complicated but also time-consuming and expensive, which often discourages local governments from undertaking this step. Improvement of the tourist attractiveness of a municipality and its environs ranked high as a location factor among the local government representatives $(27.0 \%$ - high importance, $44.7 \%$ - moderate importance). The least importance was ascribed to property tax exemption (11.6\% very important, 30.2\% - moderately important, $23.7 \%$ - not very important). However, tax relief schemes also have a positive influence on business location decisions, which has been indicated by numerous studies, and local authorities should make efforts to ensure that tax exemptions are implemented in the future to attract investments.

\section{References}

Berman O., Sanajian N., Wang J., 2017, Location Choice and Risk Attitude of a Decision Maker, Omega, Volume 66, Part A, pp. 170-181.

BUDNER W., 2004, Lokalizacja przedsiębiorstw. Aspekty ekonomiczno-przestrzenne i środowiskowe (Location of Enterprises. Economic, Spatial and Environmental Aspects), Wydawnictwo Akademii ekonomicznej w Poznaniu. Poznań.

CUll R., Xu L.C., YANG X., ZHOU L., ZHU T., 2017, Market Facilitation by Local Government and Firm Efficiency: Evidence from China, Journal of Corporate Finance, Volume 42, pp. 460-480,

DYLEWSKI M., 2006, Zagospodarowanie przestrzenne i jego wptyw na rozwój przedsiębiorczości w gminie (Space Development and its Impact on Initiative in Local Government), Ekonomiczne i organizacyjne instrumenty wspierania rozwoju lokalnego i regionalnego. Zeszyty Naukowe Nr 437, WNUŚ, Szczecin, pp. 41-55.

DZIEMIANOWICZ W., 2008, Konkurencyjność gmin w kontekście relacji władze lokalne - inwestorzy zagraniczni (Competitiveness of Municipalities in the Context of Relations of Local Authorities - Foreign Investors), Uniwersytet Warszawski, Warszawa.

FIERLA I., 1973, Geografia przemystu Polski (Geography of the Polish Industry), PWE, Warszawa.

GACZEK W. M., 2003, Zarzadzanie w gospodarce przestrzennej (Management in Spatial Economy), Poznań: Oficyna Wydawnicza Branta, Bydgoszcz.

GODLEWSKA-MAJKOWSKA H. 2016. Monitorowanie ryzyka lokalizacji w lokalnych jednostkach samorzadu terytorialnego (Monitoring the Location Risk in Local Government Units), In: KUCIŃSKI K. (red.) Lokalizacja działalności gospodarczej a jej ryzyko (Location of the Business and its Risk). CeDeWu, Warszawa, pp. 161-193.

KŁOSIEWICZ-GóRECKA U., 2007, Zagraniczne inwestycje w handlu na rynkach lokalnych (Foreign Investments in Trade on Local Markets), PWE, Warszawa.

KUCIŃSKI K. (red.) 2014, Ryzyko lokalizacji przedsiębiorstw w Polsce (The Risk of Enterprise Location in Poland), CeDeWu, Warszawa 2014, pp. 9-12.

LIZIŃSKA W., ŹRÓBEK-RÓŻAŃSKA A., 2009, Potrzeba zintegrowanych działań władz lokalnych i specjalnej strefy ekonomicznej w pozyskiwaniu inwestorów (The Need for Integrated Activities of Local Authorities and Special Economic Zone to Attract Investors), Studia i Materiały Towarzystwa Naukowego Nieruchomości. Tom 17 (3), pp. 95-102.

MiCKIEWICZ P., NOWAK M. J., 2013, Zarzadzanie przestrzenia na szczeblu lokalnym w gminach atrakcyjnych turystycznie i przyrodniczo (Spatial Management at Local Level within Municipalities Attractive for Tourism and Nature), Zeszyty Naukowe Ostrołęckiego Towarzystwa Naukowego 27, pp. 403-414.

MisZCZUK A., MisZcZUK M., ŻUK K., 2007, Gospodarka samorządu terytorialnego (The Economy of a Local Government), PWN, Warszawa.

NiEDZIÓŁKA D., 2016, Ryzyko lokalizacji elektrowni wiatrowych (The Risk of Wind Farm Location), In KUCIŃSKI K. (red.) Lokalizacja działalności gospodarczej a jej ryzyko (Location of the Business and its Risk), CeDeWu, Warszawa, pp. 17-58.

OKOŃ-HoRODYŃSKA E., 2011, Potencjat rozwojowy wybranych gmin w Polsce (Development Potential of Selected Communes in Poland), Warszawa: Wydawnictwo Uniwersytetu Warszawskiego.

PARTOVI F.Y., 2006, An Analytic Model for Locating Facilities Strategically, Omega, Volume 34, Issue 1, pp. 41-55. 
PARYSEK J. J., 1997, Podstawy gospodarki lokalnej (Basics of the Local Economy), Wyd. Naukowe UAM, Poznań.

PŁAZIAK M, SZYMAŃSKA A.I., 2014, Rola nowoczesnych czynników lokalizacji w procesie decyzyjnym przedsiębiorstw na przykładzie firm sektora budowlanego (The Role of Modern Location Factors in Decisionmaking Processes of Enterprises Based on the Example of the Construction Sector), Prace Komisji Geografii Przemysłu Polskiego Towarzystwa Geograficznego. Nr 28, pp. 144-161.

RAMíREZ-ALESÓN M., FLETA-Asín J., 2016, Is the Importance of Location Factors Different Depending on the Degree of Development of the Country? Journal of International Management 22 (2016), 29-43.

RAPORT: Atrakcyjność inwestycyjna województw i podregionów polski 2016 (Investment Attractiveness of Voivodeships and Subregions in Poland 2016), Instytut Badań nad Gospodarką Rynkową.

RinAldi F.M., 2016, From Local Development Policies to Strategic Planning-Assessing Continuity in Institutional Coalitions, Evaluation and Program Planning, Volume 56, pp. 76-87.

SZAJA M., 2009, Polityka przestrzenna jako narzędzie kreujace rozwój lokalny: próba oceny (Spatial Policy as a Tool which Creates Local Development - Trial of Evaluation), Ekonomiczne Problemy Usług. Nr 37, pp. 154-161.

SZAJA M., 2016, Lokalna gospodarka przestrzenna w aspekcie planowania wieloletniego (Local Spatial Economy in the Aspect of Long-term Planning), Finanse, Rynki Finansowe, Ubezpieczenia, Nr 6/2016 (84), cz. 2, pp. 99-111.

SzTANDO A., 2003, Progospodarcza polityka przestrzenna gmin (Economic and Spatial Policy of Municipalities), Prace Naukowe Akademii Ekonomicznej we Wrocławiu. Gospodarka lokalna w teorii i praktyce. Nr 979, pp. 193-201.

Ustawa z dnia 27 marca 2003 r. o planowaniu i zagospodarowaniu przestrzennym, Dz. U. nr 80, poz. 717 z późn. zm.). (Act of 23 March 2003 on Planning and Spatial Development, Journal of Laws, 2003, no. 80, item 717 , as amended).

Wolny A., ŹRÓBeK-RÓZAŃSKA A., ŹRÓBeK R., PiotrowsKi M., Frey J., 2014, Development of Areas and Public Purpose Investments in Suburban Territories. Real Estate Management and Valuation, Volume 22, Issue 2, pp. 86-97.

WOŹNIAK M., 2014, Przedsiębiorczość turystyczna kierunkiem rozwoju atrakcyjnych krajobrazowo gmin wiejskich (Tourist Entrepreneurship as the Direction of the Development of Landscape-Attractive Rural Communities), Prace Naukowe Uniwersytetu Ekonomicznego we Wrocławiu. Nr 366, pp. 605-617.

Zhenga D., SHI M., 2018, Industrial Land Policy, Firm Heterogeneity and Firm Location Choice: Evidence from China. Land Use Policy 76 (2018) 58-67. 